\title{
Impacts of Pressurized Irrigation Technologies on Efficient Water Resources Uses in Semi-Arid Climate of Konya Basin of Turkey
}

\author{
Bilal Acar*, Ramazan Topak, Mithat Direk \\ Selçuk University, Agricultural Faculty, Konya, Turkey, 42075
}

\begin{abstract}
Performance evaluation of irrigation has been an important area of research for better management of water resources. The present study was carried out to evaluate the performance of pressurized irrigation systems by using the previous researches conducted by our team in the Konya Basin of Turkey. The uniformity coefficient, UC and distribution uniformity, DU, as a performance parameter were analyzed. The average UC and DU values for drip irrigated areas were $80.9 \%$ and $68.9 \%$, respectively. These values for sprinkler irrigated lands were $86.8 \%$ and $79.9 \%$, respectively. The overall result showed that both UC and DU values were lower in drip irrigation than sprinkler irrigation. In general, sprinkler irrigation system has been applied for a long time while drip irrigation system has been used only recent years in Konya Closed Basin so low uniformity in drip irrigation system might be attributed to the poor experience of farmers especially about management and maintenance. It can be concluded that pressurized irrigation systems are efficient irrigation methods and should be widely used in agriculture especially in arid and semi-arid regions of the world under good management for sustainable water resources use.
\end{abstract}

Keywords: Konya Closed Basin, Pressurized Irrigation Systems, Irrigation Uniformity, Water Application Efficiency

\section{Introduction}

The climate of Konya Closed Basin, KCB, of Turkey is characterized as semi-arid and may be one of the most important problems for agriculture encountered is insufficient water resources, since rainfall is remarkably lower than average of Turkey. Therefore, there is a need to develop effective irrigation systems for the region in order to irrigate a larger area with same amount of water.

Modern irrigation technologies have high water savings under well management especially arid and semi-arid regions of the world. Some advantages of drip and sprinkler irrigation systems are; due to the high irrigation efficiency, size of the irrigated land with current water supply is higher comparison to surface irrigated areas and is possible to obtain high crop yield as well as more income with better management.

Farmers in KCB are very familiar with sprinkler irrigation systems and tend to use old sprinkler parts due to high costs and this creates some problems like uneven water distribution in the irrigated lands.

Drip irrigation is becoming more popular recently in KCB. Sprinkler irrigation has been used mostly in field crops and

\footnotetext{
${ }^{*}$ Corresponding author. Tel.: +332 2232851

Fax: +332 2410108; E-mail: biacar@selcuk.edu.tr

(C) 2010 International Association for Sharing Knowledge and Sustainability

DOI: $10.5383 /$ swes.0101.001
}

drip irrigation has been used mainly for fruit gardens, some field crops such sugar beet and corn in region.

\begin{abstract}
A poor designed and managed pressurized irrigation systems result in non-uniform water distribution. In such systems, the most valuable outcome of evaluation process is irrigation uniformity. The uniformity coefficient, UC, is an indicator of how equal or unequal the application rates resulting from the delivery devices are. The productivity of a crop is directly related to the amount of water it receives, and irrigation therefore needs to be as uniform as possible.
\end{abstract}

It is recommended that performance evaluation may be carried out soon after the system's installation, and periodically repeated, especially when considering systems, due to their sensitivity to operational conditions along the time [1].

In sprinkler irrigation, water distribution pattern depends on system design parameters (sprinkler spacing, operation pressure and nozzle diameter) and on environmental variables such as wind speed and direction [1] - [3].

Uniformity of drip irrigation systems is usually a combination of measuring the variability of emissions from individual emitters and pressure variations within the entire system.

Distribution uniformity, DU, also has been one of the most frequently used criteria for pressurized irrigation design and evaluation. Improvement of DU and well management of the 
irrigation system may lead to substantial savings in cost and the volume of water applied. This paper, therefore, mainly focused on the performance evaluation of sprinkler and drip irrigation systems for KCB.

\section{Materials and Methods}

$\mathrm{KCB}$ is situated in central Anatolian Region of Turkey and about 1000-1050 m above sea level with irrigable land of approximately 3.16 million ha. In this area about 1.86 million ha are cultivated, and 1.3 million ha are fallowed every year. Currently, 542000 ha are irrigated [4] and climate is considered to be typical semi-arid with $326 \mathrm{~mm}$ rainfall/ year [5]. Most parts of Konya, Karaman, Niğde and Aksaray cities belong to the Konya basin (Fig. 1). Total arable land potential of those cities is 3.16 million ha and accounts of $12.2 \%$ of total arable land of Turkey.

The $72.5 \%$ of total amount is in Konya plain. On the other hand, it has the $2.5 \%$ of total available water potential of Turkey. Water resources of basin are mostly groundwater and are very scant. Thus, water is an essential resource for agricultural crop production and is the single most important factor in limiting crop production in these areas [4]

The present study was carried out to evaluate the performance of pressurized irrigation systems by using the previous studies conducted by our team in the KCB of Turkey. In study, some performance indicators in pressured irrigation systems were evaluated such as uniformity coefficient, UC, distribution uniformity, DU, and also application efficiency, Ea.

Performance evaluation for sprinkler systems were conducted by adopting some suggested the methodologies [6] - [9]. Uniformity of a sprinkler irrigation system was classified as very good, good, poor, and worst when UC value is $\geq 90 \%$, between $80 \%$ and $89 \%$, between $70 \%$ and $79 \%$, and $<69 \%$, respectively [10].

Water application efficiency (Ea) for sprinkler irrigation was classified as $60 \%-70 \%$ (poor irrigation management), $80 \%$ (adequate management), and 90\% (excellent management), [11].

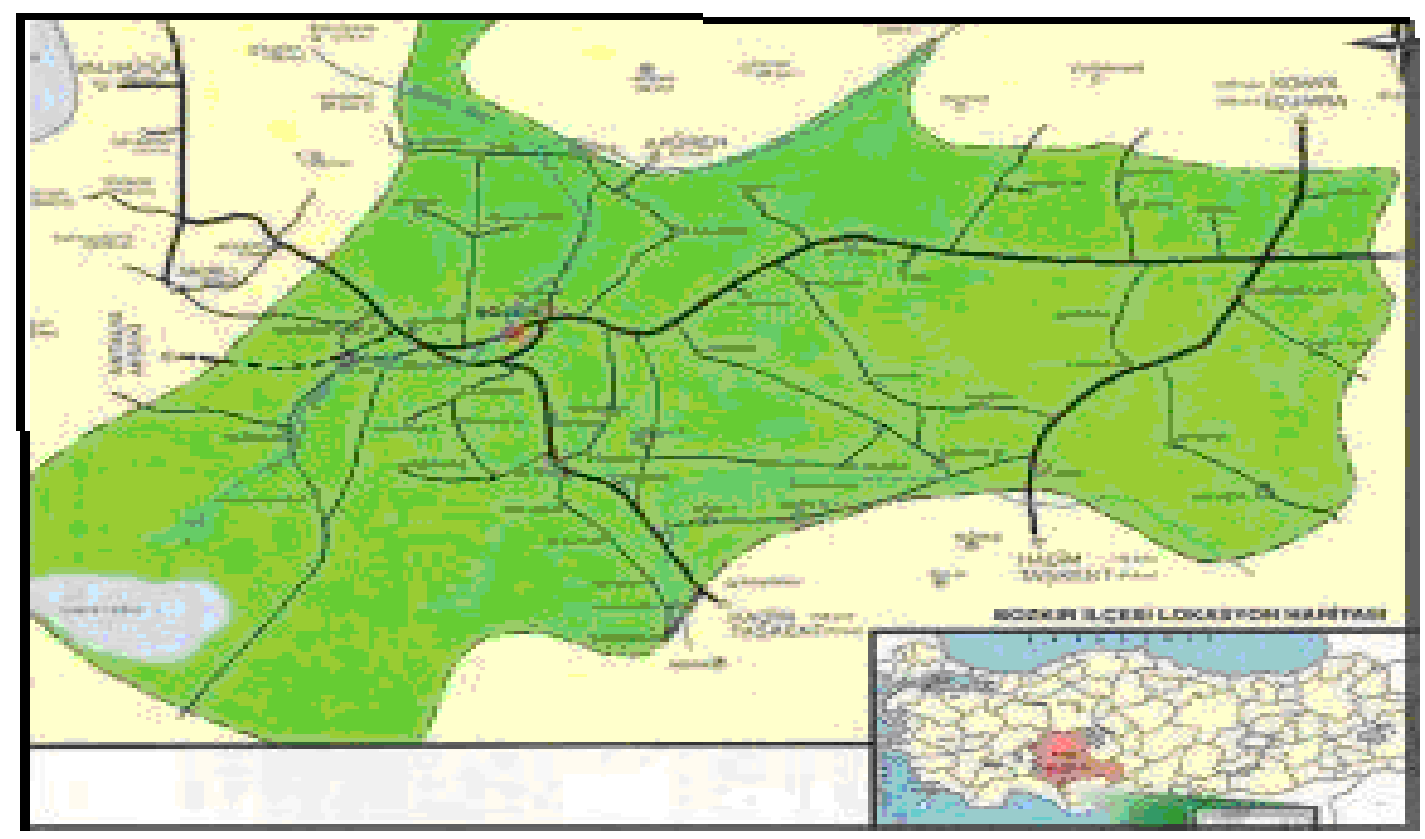

Fig. 1. General view of the Konya Closed Basin

Table 1. Uniformity coefficient, UC, \% for sprinkler and drip irrigation in KCB

\begin{tabular}{lllccc}
\hline & Study No. & Minimum & Maximum & average & References \\
\cline { 2 - 5 } Sprinkler & 1 & 72.7 & 91.8 & 83.6 & {$[12]$} \\
& 2 & 66.1 & 90.2 & 80.6 & {$[13]$} \\
\hline \multirow{2}{*}{ Drip } & 1 & 89.0 & 97.5 & 94.0 & {$[15]$} \\
& 2 & 79.2 & 94.5 & 89.9 & {$[16]$} \\
& 3 & 44.2 & 82.6 & 68.8 & {$[17]$} \\
\hline
\end{tabular}




\section{Results and Discussion}

UC values, measured by our team, are given in Table 1 . The average UC values were measured as $83.6 \%$ in one and $80.6 \%$ in our other previous studies for sprinkler irrigation systems. There were little differences between those two studies and water uniformity was classified as good [10] according to UC values in both studies. According to the evaluation, sprinkler irrigation water distribution pattern depended on system design parameters such as sprinkler spacing, operation pressure and nozzle diameter and on environmental variables like wind speed and direction [1] - [3]. The influence of different design and performance factors, such as subunit arrangement, lateral spacing, working pressure, average application rate, and application efficiency of water application cost, in a permanent set sprinkler irrigation system was also reported [14]. The result like the previous findings of our team showed that the most important factor affected to uniformity was sprinkler spacing.

The UC values were as averages of $94.0 \%, 89.9 \%$ and $68.8 \%$ for drip irrigation in three different studies of our team. The distributions were classified as excellent, good or almost excellent and poor according to the UC values [18] and [19]. A poor designed and managed drip irrigation system with considerable pressure variation, clogged emitters mainly affected uniform water distribution in study areas. Therefore, after carefully design and installation of drip systems, maintenance-and repair works should be carefully performed to obtained uniform water distribution through the field. Under high uniformity conditions, almost all crops uptake water equally so crop yield and quality are positively affected.

The values of DU were minimum, 54.7\%; maximum, $84.0 \%$ and average, $71.5 \%$ depending on the lateral spacing, wind speed and working pressure for sprinkler irrigation (Table 2). The lowest value of DU (54.7\%) is lower than the threshold (DU $=60 \%$ ) established by [1].
In drip system, the values of DU were minimum, $42.1 \%$; maximum, $83.5 \%$ with average, $68.9 \%$. According to the average of DU (68.9\%), water distribution was poor by [6] and unacceptable by Classification by Instituto de Reforma Y Desarrollo Agrario, IRYDA, [20]. In one study [21], the average DU was $96.4 \%$ and in other study [22] it was demonstrated that $84.0 \%$ distribution uniformity for localized irrigation systems from Castilla-La Mancha-Spain with an average value of $82.0 \%$. Our team findings are lower than these studies [21] , [22]. In our team studies, failure might be mainly caused by poor design, installation, maintenance and operation. We observed that the uniform water distribution was mainly affected from pressure variations through the pipe lines. The variations were resulted from different factors such as topography and length of laterals. It is, therefore, difficult to precisely characterize the pattern of uniformity without a large number of measurements in drip and sprinkler systems. In general, the average UC and DU values for drip and sprinkler systems measured by our team were $80.9 \%$ and $68.9 \%$; and $86.8 \%$ and $79.9 \%$, respectively. The overall result showed that $\mathrm{UC}$ and DU values were lower in drip irrigation than sprinkler irrigation. The reason might be that sprinkler irrigation system has been applied for a long time while drip irrigation system has been used recently in basin. Farmers used drip irrigation systems don't have enough information about the design, installation, maintenance and repairs of the drip irrigation system.

Water application efficiency, Ea, previously measured by our team in KCB for sprinkler irrigation is presented in Table 3. In one study, Ea varied from $64.1 \%$ to $85.4 \%$ with an average of $81.4 \%$. According to minimum and maximum, Ea were classified [11] as poor and excellent, respectively. The average Ea values measured by our team in other two studies were $76.2 \%$ and $76.6 \%$, respectively and efficiency was classified as adequate in both researches. There were also some studies carried out in KCB. In their reports, Ea was as 75-85\% [24] and as $31-74 \%$ [25]. The previous results of our team are in line with those two studies.

Table 2. Distribution uniformity, DU, \% for sprinkler and drip irrigation in KCB

\begin{tabular}{llllll} 
& Study No & Minimum & Maximum & average & References \\
\cline { 2 - 6 } Sprinkler & 1 & 54.7 & 84.0 & 71.5 & {$[13]$} \\
\hline Drip & 1 & 42.1 & 83.5 & 68.9 & {$[17]$} \\
\hline
\end{tabular}

Table 3. Water application efficiency, Ea, \% for sprinkler irrigation systems

\begin{tabular}{lllll}
\hline Study No & Minimum & Maximum & average & References \\
\hline 1 & 64.1 & 85.4 & 81.4 & {$[12]$} \\
2 & 63.2 & 84.9 & 76.2 & [23] \\
3 & 63.8 & 90.0 & 76.6 & \\
\hline
\end{tabular}




\section{Conclusion}

Water resources of KCB are mostly groundwater and are very scant. Agriculture with present status has resulted excess water uses in Basin. Thus, this limited water supply should be used efficiently to be irrigated more areas with same water. Pressurized irrigation techniques are very reliable solution for obtaining higher uniformity and application efficiency under well management. In general, sprinkler irrigation has very long history in basin so farmers have deep experiences about sprinkler system. This resulted in both good water distribution uniformity and application efficiency. In addition, excess water uses from the basin resources should be avoided by increasing the land size of low water consuming crops. Future studies should be focused on mainly drip irrigation and also sprinkler management. To sustain the water resources especially in arid and semi-arid regions like $\mathrm{KCB}$, modern irrigation technologies such as sprinkler or drip systems should be widely used under good management.

\section{References}

[1] Keller J, Bliesner RD. Sprinkle and Trickle Irrigation', AVI Book. Van Nostrand Reinhold, New York, 1990.

[2] Seginer I, Kanz D, Nir D. The distortion by wind of distribution patterns of single sprinklers. Agric. Water Manage. 1991;9: 341-359.

[3] Tarjuelo JM, Valiente M, Lozoya J. Working conditions of a sprinkler to optimize the application of water. J. Irrig. Drain. Engng. 1992; 118 (6): 895-913.

[4] Topak, R, Süheri S, Acar B. İklim-Tarımsal KuraklıkSulama ve Çevre Etkileşimi Yönünden Konya Havzası. Konya Closed Basin Groundwater and Drought Conference, 11-12 September, Konya, 2008 (in Turkish).

[5] DMİ: Çumra Rasat İstasyonu Çok Yıllık İklim Verileri. Devlet Meteoroloji İşleri Genel Müdürlüğü, (State Meteorological Service), Konya, Turkey, 2003.

[6] Merriam JL, Keller J: Farm Irrigation System Evaluation: A Guide for Management. Logan, Utah: Utah State University, 1978.

[7] Merriam, JL, Shearer MN, Burt CM: Evaluating Irrigation Systems and Practices. In Design and Operation of Farm Irrigation Systems, Ed. M.E Jensen, 721-760. St. Joseph, Mich.: ASAE, 1980

[8] ASAE Standards, S330.1. Procedure for Sprinkler Distribution Testing for Research Purposes. St. Joseph, MI.: ASAE, 1985a.

[9] ASAE Standards, S398.1 Procedure for Sprinkler Distribution Testing for Research Purposes. St. Joseph, MI.: ASAE, 1985b.

[10] Little GE, Hills DJ, Hanson BR. Uniformity in pressurized irrigation systems depends on design, installation California Agriculture. 1993; 47:18-21.

[11] Tarjuelo JM, Ortega JF, Montero Juan JA. Modeling evaporation and drift losses in irrigation with medium size impact sprinklers under semi-arid conditions. Agric. Water Manag.'. 2000; 43: 263-284.
[12] Topak R. Application Problems of Sprinkler Irrigation in Konya Çumra Region. Ph.D. Thesis, Dept. Farm Buildings and Irrig., Selçuk Univ., Konya, 1996.

[13] Topak R, Süheri S, Çiftçi N, Acar B. Performance evaluation of sprinkler irrigation in Semi-arid area. Pakistan Journal of Biological Sciences. 2005; 8 (1): 97 103.

[14] Martinez JM, Martinez RS, Tarjuelo JM. Analysis of water application cost with permanent set sprinkler irrigation systems. Irrig. Sci. 2004; Springer-Verlag 2004/s71-004-0098-6.

[15] Acar B. The Effect of Different Emitter Discharges on Soil Moisture Distributions in Soil Profile. Ph.D. Thesis, Dept. Farm Buildings and Irrig., Selçuk Univ., Konya, 2001.

[16] Bağdatlı MC, Acar B. Evaluation of trickle irrigation systems for some vegetable crops in Konya-Turkey. J. Int. Environmental Application \&Science, 2009; 4 (1):79-85.

[17] Düzgün BG. Determination of Uniform Water Distributions of Trickle Irrigation Systems Installed in Apple Gardens in Aksaray Province. MSc. Thesis, Dept. Farm Buildings and Irrig., Selçuk Univ., Konya, 2009.

[18] Bralts VF, Edwards DM, Kesner CD. Field evaluation of drip/trickle irrigation submain units. Third International Drip/Trickle Irrigation Congress, Fresno-California, U.S.A., 1985, pp, 274-280.

[19] Tüzel İH. Evaluation of irrigation uniformity in trickle irrigation systems. J. Ege University, Agric. Faculty, 1993; 30 (1-2):119-126 (in Turkish).

[20] IRYDA (Instituto de Reforma Y Desarrollo Agrario), “ Normas para la redacción de proyectos de riego localizado. Ministerio de Agricultura, Pesca y Alimentación, 1983, Madrid, Spain.

[21] Çamoğlu G, Yavuz MY. The effect of manufacturing variation coefficient on irrigation uniformity of in-line and on-line drippers. Akdeniz University, Journal of Agricultural Faculty. 2006; 19 (1):1-8 (in Turkish).

[22] Ortega JF, Tarjuelo JM, De Juan JA. Evaluation of irrigation performance in localized irrigation systems of semiarid regions (Castilla-La-Mancha-Spain). Agricultural Engineering International: the Cigr Journal of Scientific Research and Development. Manuscript. LW 01 007. 2002;4.

[23] Topak R, Acar B, Kara M, Çiftçi N, Şahin M. Effect of new management on performance criteria in irrigation Networks of Çumra and Ova Irrigation Associations. 2 National Irrigation Congress", Pine Beach Holiday Resort- Kuşadası/Aydın-Turkey, 16-19 October 2003.

[24] Balaban A, Ayyıldız M: Orta Anadolu Sulamalarında Tarla Sulama Randımanı Üzerine Bir Araştırma. Ankara, 1970 (in Turkish).

[25] Çakmak B. Konya Çumra Ovasında Su Dağıtım ve Uygulama Randımanının Belirlenmesi. Ph.D. Thesis, Dept. Farm Buildings and Irrig., Ankara Univ., Ankara, 1994 (in Turkish). 